Marc Loth*

\title{
How does Tort Law deal with Historical Injustice?
}

\author{
On Slavery Reparations, Post-Colonial Redress, and the \\ Legitimations of Tort Law
}

https://doi.org/10.1515/jetl-2020-0141

\begin{abstract}
How does tort law deal with historical injustice? This question appears of increasing relevance since the global quest for the reparation of historical injustices influences tort law. This contribution seeks to offer an answer to it by addressing three sub-questions: (1) how may reparation be claimed, that is, what kind of reparation claims are possible and what problems do they encounter?; (2) why should these claims be sustained, that is, how do they fit in the traditional legitimation patterns of tort law?; and (3) when are they most likely to be sustained, that is, what conditions will enhance their chances of success? In this article I draw on examples from the slavery reparation suits in the US, post-colonial redress cases in the Netherlands, and sexual abuse cases against clergymen (amongst others). I conclude that only under specific circumstances can tort law offer a remedy for historical injustice. Amongst the variables of successful claims are the period of time that has lapsed, the nature of the parties, the remedies claimed, the moral legitimation, and political considerations. This list is not closed, however, since many more cases are to be expected.
\end{abstract}

Note: This paper is based on the book chapter that I wrote for the Dutch Association of Civil Law: MA Loth, Houdbaar recht, over de aansprakelijkheid voor historisch onrecht, in: MA Loth/LPW van Vliet (eds), Recht over tijd, hoever reikt het Privaatrecht in het verleden? (2018) 5-81.

*Corresponding author: Marc Loth, Professor of private law at Tilburg University, and former member of the Dutch Hoge Raad (The Supreme Court of the Netherlands in the fields of civil, criminal and tax law), E-Mail: m.a.loth@tilburguniversity.edu 


\section{Introduction}

In law, society and politics, we witness a cultural turn towards gross historical injustices, and perhaps even towards history in general. ${ }^{1}$ For centuries, history has been a relatively quiet possession, in the sense that the actual state of affairs was considered to be legal because it was the result of times immemorial. Gross historical injustices were left alone ('let bygones be bygones'). ${ }^{2}$ Since the collapse of the great empires and ideologies, however, history has left a trace of (groups of) victims who want their stories to be heard and their suffering to be recognised. Indigenous people, suppressed minorities, inhabitants of former colonies, victims of the Holocaust, and many others, all over the world, have searched for recognition of their sufferings in the more or less recent past, or even for legal reparations in any form. Together they have caused a 'democratisation of history'3 as well as 'a policy of regret'. ${ }^{4}$ Societies across the globe aspire to come to terms with their past nowadays: by storytelling, memorial statues or exhibitions, the rewriting of educational material, apologies of governments, financial compensation facilitated by special laws and funding, or even the criminal prosecution of the perpetrators. Whatever form the reparation of historical injustice takes, the goal is a political reconciliation that facilitates the peaceful coexistence of the opposed parties. But there is a downside as well: the risk is that the aspired reparation leads to new controversies, this time on the meaning and impact of the contested past. The reparation of historical injustice may even lead to new injustice, since it requires a redistribution of goods and opportunities. The question whether to repair or to forget historical injustice is therefore not an innocent one. ${ }^{5}$

Neither is the question whether tort law has any role to play here and if so, what this role entails. How does tort law deal with historical injustice? What pos-

1 B Bevernage, The past is evil/evil is past: on retrospective politics, philosophy of history, and temporal manichaeism (2015) 54 History and Theory 334. For an explanation see J Torpey, The pursuit of the past: a polemical perspective, in: P Seixas (ed), Theorizing Historical Consciousness (2004) 240.

$2 \mathrm{~W}$ van Iterson, Immemoriale possessie and praescriptie in de Nederlandse rechtsgeschiedenis (1962) Rechtsgeleerd Magazijn Themis (RMThemis) 427.

3 A Cairns, Coming to terms with the past, in: J Torpey (ed), Politics and the Past. On Repairing Historical Injustices (2003) 48; E Barkan, Restitution and amending historical injustices in international morality, in: J Torpey (ed), Politics and the Past. On Repairing Historical Injustices (2003) 67. 4 JK Olick/B Coughlin, The politics of regret, analytical frames, in: J Torpey (ed), Politics and the Past. On Repairing Historical Injustices (2003) 2.

5 CS Maier, Overcoming the past? Narrative and negotiation, remembering and reparation: issues at the interface of history and the law, in: J Torpey (ed), Politics and the Past. On Repairing Historical Injustices (2003) 260. 
sibilities and limitations does it offer for justice-seekers, or for a society trying to come to terms with its past? ${ }^{6}$ How do claims for compensation of the consequences of historical injustices fit in the legitimation patterns of tort law? And under what conditions can they be expected to be successful? These questions seem to become more pressing by the day, since a growing number of claims on the ground of committed or pretended historical injustice reach the civil courts across a number of jurisdictions. Whatever the historical background - slavery in the US, post-colonial liberation in Asia or Africa, the abuse of minors in the Roman Catholic Church in Europe - the question for tort law is, of course, whether injustice in a more or less remote past can be a ground for liability today. So far, the most important hurdle for justice-seekers in most legal systems is the statute of limitations, withholding the possibility of a legitimate claim after a certain period of time (in most jurisdictions twenty or thirty years). The legitimation is found in both the particular interests of the parties involved (the right of the defendant to be safeguarded against pretentions from a long time ago, the duty of the claimant to claim in due time) as well as the public interests of society at large (the possibility of a fair trial on the ground of established facts, the legal certainty that the status quo mirrors the legal state of affairs). In many legal systems, a statute of limitations can be tolled or lifted, however, recently even in a case of historical injustice (Section II). This in itself is a sign that tort law is already affected by the quest for reparation of gross historical injustices.

This contribution addresses three questions in particular: (1) How is reparation to be claimed, that is, what kinds of reparation claims are there? (2) Why should claims for reparation of historical injustice be sustained, that is, how do they fit in the legitimation patterns of tort law? (3) When are they most likely to be sustained, that is, what conditions will enhance their chances of success? Some preliminary remarks about these questions are in order. First, the answer to the when-question differs according to different legal systems, of course, but it is not my intention to offer a detailed comparative analysis here. Instead, I restrict myself to the general patterns of claims for reparation of historical injustice and the problems they raise for any legal system. In other words, my concerns are at this stage more of a conceptual than of a comparative nature. Still I need some feet on the ground and will therefore present examples from the US and from my own (Dutch) legal system that seem to be representative (Section II). Next, the answer to the why-question is less system-dependent, since the goals and legitimations of

\footnotetext{
6 AL Brophy, Some conceptual and legal problems in reparations for slavery (2003) 58 New York University Annual Survey of American Law (NYU Ann Surv Am L) 497; AL Brophy, Reparations Pro \& Con (2006).
} 
tort law in different modern Western legal systems by and large coincide. Since the reparation of gross historical injustice is a relatively new phenomenon for tort law, we will investigate whether it fits in the regular legitimation patterns like compensation, retribution, satisfaction, or distribution (Section III). After investigating both questions, we will see that the success of a claim for the reparation of historical injustice depends mainly on the lapse of time passed, the nature of the parties involved, the remedies claimed, the legitimations to be found, and the political considerations to be made (Section IV). These findings provide a conjectural answer to the question in the title of this contribution, but (again) they need to be concretised in specific legal systems.

\section{Two types of claims}

In the context of the debate on slavery reparation suits, a useful distinction has been drawn between ancestor-based claims and descendant-based claims. ${ }^{7}$ Ancestor-based claims are based on past harm, wrongfully inflicted upon the victim (slave) in the remote past ('past harms'), causing injury or harm at the time for which recourse is sought now. Descendant-based claims are based on presentday damage that the plaintiff slave-descendant suffers today and for which he or she seeks recourse ('present ill-effects'). Of course, both types of claim may concur, in the sense that any litigant may seek to raise both ancestor-based claims and descendant-based claims at the same time. In the case of Farmer-Paellmann $v$ FleetBoston Financial Corporation, for example, the plaintiff sought 'accounting, disgorgement of profits, the creation of an independent historical commission to study the Defendants' actions, a constructive trust, restitution and compensatory and punitive damages arising out of the named Defendant's alleged past and continued wrongful conduct relating to the institution of slavery'. ${ }^{8}$ Although concurrence is possible, the conceptual distinction is important, because it explains the different kind of obstacles plaintiffs encounter.

7 KD Wenger, Causation and Attenuation in the Slavery Reparations Debate (2006) University of San Francisco Law Review (USF L Rev) 279; $R$ Fortson, Correcting the Harms of Slavery: Collective Liability, the Limited Prospects of Class Action Suit for Slavery Reparations, and the Reconceptualization of White Racial Identity (2004) 6 Berkeley Journal of African-American Law \& Policy (BJALP) 87; KN Hylton, Slavery and Tort Law (2004) 84 Boston University Law Review (BU L Rev) 1209 (on derivative claims, brought by someone other than the direct victim), <https://papers.ssrn. com/abstract $=374200>$.

8 In Re African-American Slave Descendants Litigation, 375 Federal Supplement, Second Series (F Supp 2d) 721 (North Dakota Reports [ND] III 2005); In Re African-American Slave Descendants Litigation, 471 Federal Reporter, Third Series (F 3d) 754 (7th Cir 2006). 


\section{A Ancestor-based claims}

Ancestor-based claims encounter three different kinds of problems, all of which are the result of the long time lapse between the alleged wrongful conduct and the actual claim, namely that the claims are barred most of the time (the statute of limitations), that they lack easily identifiable victims and wrongdoers (victim- and wrongdoer-attenuation), and that the wrongfulness is disputable (legality). I will address these problems respectively.

As mentioned in the Introduction, the statute of limitations can be tolled or lifted, especially in cases of hidden damage. Classic is the case of the victim suffering from a mesothelioma as a result of exposure to asbestos. ${ }^{9}$ A mesothelioma is a tumour with an incubation period of 30 to 40 years, which means that a possible claim against the employer is already barred before the victim discovers that he suffers from this disease. In such a case, the appeal of the employer on the statute of limitations is, under Dutch law, considered to be unacceptable according to measures of equity and reasonableness. ${ }^{10}$ Only recently the District Court of The Hague extended this established case law to a case of historical injustice, based on events on 7 December 1947 in the village of Rawagedeh in Indonesia (then an acclaimed Dutch colony). ${ }^{11}$ During a military operation, Dutch soldiers executed the men of Rawagedeh, an execution which was characterised in a UN report of January 1948 as 'deliberate and ruthless'. When the widows of the victims filed their claims for compensation against the Dutch State in 2009, and the State appealed for the statute of limitations, the court ruled this appeal unacceptable according to measures of equity and reasonableness, given (i) the exceptional and unprecedented circumstances of the case, (ii) for which the State is culpable also according to then prevalent standards, (iii) the passive attitude of the State since then despite its knowledge of the facts, and (iv) the facts - although old - refer to a period in history that is not yet closed. This decision - that has been repeated in similar cases, also with regard to the children of the victims - has opened the gate for claims on the ground of histor-

9 Hoge Raad (HR) 28 April 2000, ECLI:NL:HR:2000:AA5636 (Van Hese/De Schelde). Since the issue surfaced initially in workmen's compensation situations such as Urie $v$ Thompson, 337 United States Supreme Court Reports (US) 163, 170 (1949), it has been extensively documented in the US. See eg RI Stevenson, Products Liability and the Virginia Statute of Limitations - A Call for the Legislative Rescue Squad (1981) 16 University of Richmond Law Review (U Rich L Rev) 223; CW Napier, Civil Incest Suits: Getting Beyond the Statue of Limitations (1999) 68 Washington University Law Quarterly (Wash U LQ) 995.

10 Article 6:2 Dutch Civil Code (Burgerlijk Wetboek).

11 Rechtbank (Rb) Den Haag 14 December 2011, ECLI:NL:RBSGR:2011:BS8793 (Rawagedeh). 
ical injustice. ${ }^{12}$ At the moment, a case is pending in which about forty elderly women are seeking compensation from the congregational order of the Sisters of the Good Shepherd for forced labour during their youth when they were held against their will in one of its convents. Like the widows of Rawagedeh, these women were excluded from the administration of justice, which robbed them of the effective remedy to which they were entitled under art 13 ECHR. These examples illustrate that the hurdles of the statute of limitations are not impregnable.

The second kind of problem ancestor-based claims encounter is the victimand wrongdoer-attenuation, which arise in cases of intergenerational justice. In slavery reparation suits, it has turned out to be difficult to connect plaintiffs from here and now to victims of then and there (victim-attenuation), as it was to connect defendants to wrongdoers (wrongdoer-attenuation). ${ }^{13}$ For legal standing, sufficient continuity is required, in the form of inheritance relations or legal personhood. For plaintiffs, the problem of wrongdoer-attenuation is easiest to solve when a private or public legal person is available - a large corporation or government - which already existed at the time, or is a clear successor of such a legal person. In the case of Farmer Paellmann, for example, she filed her claims against various corporate defendants which she held liable for the commercial activities of their alleged predecessors before, during and after the Civil War in America. She herself claimed to be the great-great-granddaughter of Clara and Abel Hinds, Africans who were enslaved on a South-Carolina sea island rice plantation. In the Rawagedeh case, things looked easier at first sight, since the widows themselves were harmed by the wrongful execution of their belated husbands, and because the defendant was the legal person directly responsible for those executions (the State of the Netherlands). Nevertheless, the identification of victims and wrongdoers is not always that easy and the success of ancestor-based claims is by and large dependent on the extent to which these issues can be solved or circumvented. $^{14}$

Besides the issue of legal standing, however, there is the moral dimension of victim- and wrongdoer-attenuation. It manifests itself in the argument that AfroAmericans of today are (or are not) sufficiently linked to slaves of then and there to claim compensation, as - on the other hand - present-day citizens, corporations or governments are (or are not) sufficiently connected to slave-owners to be

12 Rb Den Haag 11 March 2015, ECLI:NL:RBDHA:2015:2449 (Peniwen and South-Sulawesi); Rb Den Haag 27 January 2016, ECLI:NL:RBDHA:2016:702 (Kebon Agung); Rb Den Haag 1 February 2017, ECLI:NL:RBDHA:2017:782 (train hijacking).

$13 \mathrm{KD}$ Wenger, Causation and Attenuation in the Slavery Reparations Debate, University of San Francisco Law Review (USF L Rev) 1 (2006) 279, $289 \mathrm{f}$.

14 Wenger, USF L Rev 1 (2006) 279, $289 f$. 
held accountable for harms caused by slavery. As a critic to ancestor-based claims puts it: 'Thus, we have a very significant harm, but not one suffered by the claimants personally. We have a gain, but not one that matches the loss. We have a wrong, but the parties who will bear the costs of judgment are not wrongdoers. ${ }^{15}$ It is not surprising therefore, that often claims are filed by or in the name of a group of victims against a group of wrongdoers for admitting slavery or profiting from it, dependent on the possibilities the specific legal system offers for class actions. ${ }^{16}$ At this point we leave the familiar ground of tort law as a system and practice of corrective justice and arguments of distributive justice enter the stage. This raises the question of whether the court is still the appropriate institution to decide on reparations of this scale, or whether the legislator is more suitable for the task. ${ }^{17}$

The last problem ancestor-based claims face is the problem of legality. The starting point here is that the wrongfulness of the act is to be judged according to standards prevailing at the time. Of course, this is not always easy to establish, especially in the case of unwritten norms, but the principle is clear. As we have seen, the court in the Rawagedeh case explicitly took into account that the executions were wrongful at the time, as was confirmed by the UN report. Slavery, however, was a legal institution until its abolishment in 1865, however objectionable we may consider it now. So how does this justify liability for compensation? For most writers, slavery reparation stops here, but others have made an attempt to circumvent the problem of legality: 'Slavery should be treated not as an institution sanctioned by law, but as a corruption or displacement of law. Law and slavery are, in essence, "universal complements", in the sense that the one can only exist in a space where the other is absent. Hence, the only morally consistent position that a state can take with respect to slavery is that it has never cohabited with that institution.' 18

According to this line of reasoning, holding someone liable for slavery is not the retroactive application of current standards - and thus a violation of the principle of legality - but the extension of law to a hitherto lawless situation. Of course, this argument can be applied to less extreme situations as well, as long as the wrongdoers could have and should have acted otherwise. The case of the forced labour at the Sisters of the Good Shepherd seems a perfect illustration. In theory and in practice, the difference between slavery and the forced labour by

15 E Sherwin, Reparations and Unjust Enrichment (2004) 84 BU L Rev 1462.

16 Fortson, BJALP 6 (2004) 87, 71-75.

17 As was decided in the case of Deardria Farmer-Paellmann v FleetBoston Financial Corporation et al on the basis of the political question doctrine.

18 Hylton, BU L Rev 84 (2004) 1209. 
girls and young women in a convent seems thin and if anyone could have and should have acted otherwise, it is the nuns of the Sisters of the Good Shepherd to whom it was entrusted to care for the girls. If we consider this line of reasoning as a legitimate solution for the problem of legality, then this case illustrates that we need to redesign the distinction between liability and wrongfulness in the case of historical injustice. Liability without wrongfulness at the time of the act seems feasible when the wrongful act is the legal solution for a lawless situation. Is there a justification for this result? If there is, this justification is not the culpability of the act or the wrongdoers, it is the distribution of the risk of moral progress. The principle is that it is justified to place the burden of moral progress on the shoulders of those who have profited from the lawless situation that is now being repaired, rather than on those who have suffered from that situation. ${ }^{19}$ The appeal to this principle seems in any case to be the most plausible way to circumvent the problem of legality that we face in the case of gross historical injustice.

\section{B Descendant-based claims}

Descendant-based claims have a different structure than ancestor-based claims. The central idea is that the claim is focused on the harms that the plaintiff as slave-descendant continues to suffer today, and for which the defendant is now being held liable. In other words, the plaintiff seeks redress for the present-day ill effects of the historical injustice. Descendant-based claims encounter three kinds of problems, all of which are (again, as in the case of ancestor-based claims) the result of the long time lapse between the original act and the actual consequences, namely that the claims are barred most of the time (statute of limitations), that the causal connection between the wrongful act and its present-day consequences is hard to identify (act-attenuation), and that the wrongfulness in the sense of the relativity or scope of the norm is not evident.

The first kind of problem is that descendant-based claims are barred most of the time because of the time which has passed. Over and above the objective lapse of time that has passed - the 20- or 30-year period that holds in most legal systems - there is the question of why the claim was not filed before. Couldn't the plaintiff have filled his claim before, of couldn't one of his or her ancestors have done so? What is the reason that the claim is submitted now, after all these years?

19 H Dagan, Restitution and Slavery: On Incomplete Commodification, Intergenerational Justice, and Legal Transitions (2004) 84 BU L Rev 1139, <https://papers.ssrn.com/sol3/papers.cfm?abstrac t_id=664403>. 
Is it that only now historical evidence is available, for example through the publication of digital registrations? It seems that only recently many people have discovered that they descend from one or more slaves and thus are confronted with the question as to how they want to deal with that hitherto unknown history. Or is it that the plaintiffs were not in a position to file a claim sooner since they simply had no access to the administration of justice (like the widows of Rawagedeh)? Different legal systems have a diversity of rules to deal with the subjective dimension of the statute of limitations and they may possibly stand in the way of a descendant-based claim. I will not go into detail here.

The second kind of problem for descendant-based claims is the problem of identifying the required causal relation between the original wrongful act and the present-day damage. Although there is a general connection between slavery and discriminatory (Jim Crow) legislation afterwards on the one hand, and the social disadvantage of many Afro-Americans on the other, it is almost impossible to conceptualise this as a causal relation between individual events as required by law. The chains of causal events and intermediate intentional interferences are too long to grasp. We simply lack the knowledge of the relevant genealogical, causal and counterfactual conditionals. Sometimes we can use familiar techniques, such as statistical evidence, that may support the view that the victims would have been better off without slavery (eg, that descendants of slaves have smaller life chances than the members of a control group). Likewise we can use the doctrine of the loss of a chance to address the problem that we never know what would have happened had the descendants' forefathers received regular wages for their work. What the plaintiff in any case lacks is the possibility that he or she would have profited from this. But these doctrines do not solve the immense problems that we are confronted with because of the complexity of the causal nexus that connect the days of slavery with today. On top of the problems of victim-attenuation and wrongdoer-attenuation, we seem to have a problem of act-attenuation on our hands: the lack of clarity with regard to the relation between the harmful acts of slavery and any present damage.$^{20}$ Connected with this problem is the assessment of damage. At best it is possible to calculate damage on the basis of many presumptions at the abstract level of parts of the population, but damage appears practically incalculable at the level of individual plaintiffs. The calculation of the intergenerational effects in particular seems to be a far cry. ${ }^{21}$

20 Wenger, University of San Francisco Law Review 1 (2006) 279, $289 \mathrm{f}$.

21 KK Charles/E Hurst, The Correlation of Wealth Across Generations (2003) 111 Journal of Political Economy 1155; $D$ Conley, Calculating slavery reparations, theory, numbers and implications, in: J Torpey (ed), Politics and the Past. On Repairing Historical Injustices (2003) 80. 
This brings us to the third kind of problem that descendant-based claims encounter, namely the question of relativity of the violated norms (or their scope): why should the plaintiff receive compensation? Were the initial acts of the wrongdoer in any way wrongful towards the plaintiff? At the time, did the conduct of the wrongdoer violate a norm protecting the plaintiff's interests today in any way? This persistent question is rather new. The idea that a wrongful act towards one person may at the same time constitute (another) wrongful act towards someone else is not unfamiliar in tort law, but the situation changes if that someone else has not been born yet. On the other hand, the fact that the wrongdoer does not know his victim since he or she has not been born yet is in itself not enough to exempt the wrongdoer. In cases of environmental damage and climate change, it is accepted that the particular interests of future individuals not yet known may constitute a public interest that at least justifies legal standing. ${ }^{22}$ Legal standing, however, is not the same as being harmed in a way and to the extent that it constitutes liability to repair the harm suffered. At the end of the day, the question of whether the initial harm inflicted upon slaves years ago constitutes liability today is a political/moral question (Section III). In any case, it is a question that has to be answered in a satisfactory way if descendant-based claims are to stand a chance. ${ }^{23}$

\section{Legitimation patterns in tort law}

So far we have seen that both ancestor-based claims and descendant-based claims run into serious difficulties, mainly because of the lapse of time that has passed since the alleged wrongful acts. As a matter of fact, no claim for reparation of the consequences of slavery has been successful thus far. ${ }^{24}$ The Dutch jurisdiction, however, has shown some cases where post-colonial crimes have been repaired, although mainly symbolically. In the mentioned Rawagedeh case, the widows claimed declaratory relief that the State had acted wrongfully and their claim was sustained. Afterwards, they negotiated a symbolic compensation

22 Oposa v Factoran, General Register (GR) No 101083, 30 July 1993, 224 Supreme Court Reports Annotated (SCRA) 792; Rb Den Haag 24 June 2015, ECLI:NL:RBDHA:2015:7145 (Urgenda); Hof Den Haag 9 October 2018, ECLI:NL:GHDHA:2018:2610 (Urgenda).

23 The only alternative being that the defendant certainly acted wrongfully towards the plaintiff, but it is hard to grasp what norm he or she violated. In any case, it is the same problem of legality that we face with regard to ancestor-based claims, yet in another disguise.

24 Hylton, BU L Rev 84 (2004) 1209. As it stands, the movement has lost its momentum (W Olsen, So long, slavery reparations, Los Angeles Times [Los Angeles, 31 October 2008]). 
amount of $€ 20,000$ per person, which again later was transformed into a rule for similar cases. ${ }^{25}$ In another case where the plaintiff claimed damages for being tortured while imprisoned by Dutch soldiers in the post-colonial period - which was partly considered to be proven - the State was ordered to pay $€ 5,000$ in immaterial damages (now pending in appeal). ${ }^{26}$ In different contexts, claims for the reparation of historical injustice have been filed, at least in the Netherlands, and sometimes sustained. The Dutch Hoge Raad has ruled in two cases that the State of the Netherlands is liable for the death of Rizo Mustafiç, and the father, mother and brother of Hasan Nuhanović. In the summer of 1995, they were sent by Dutch soldiers from the UN compound in eastern Bosnia, with the foreseeable risk of being killed by the Bosnian Serb army. ${ }^{27}$ After these rulings, the foundation, The Mothers of Srebreniça, and individual descendants of victims of the fall of that 'safe area' filed claims against the State of the Netherlands for the loss of their husbands and sons. The Appellate Court sustained their claims partially, depending on the circumstance (amongst others) of whether they were staying in- or outside the compound. ${ }^{28}$ As we have seen, in yet another context claims have been filed - and still continue to be filed - for the reparation of the consequences of sexual abuse by clergy from the Roman Catholic Church. All in all, it seems that a continuous stream of claims for reparation of historical injustices is just starting, and that we are facing a new development that may shape tort law in the coming years.

This development raises the issue of the legitimacy of claims for the reparation of historical injustice: should they be sustained, and if so, on what grounds? What kind of normative - moral or political - reasons are there for the reparation of historical injustice by the civil court? And how do these reasons fit in the traditional legitimations of tort law? Thus we switch from the what-question to the why-question, that is the question if and how liability for historical injustice fits in the normative foundations of tort law. Starting from the classical approach of tort law as a system and practice for the compensation of unjustly inflicted harm, we will find that the principle of corrective justice is controversial if applied to

25 'Bekendmaking van de Minister van Buitenlandse zaken en de Minister van Defensie van 10 september 2013 (...) van de contouren van een civielrechtelijke afwikkeling ter vergoeding van schade aan weduwen van slachtoffers van standrechtelijke executies in het voormalige Nederlands-Indië van vergelijkbare ernst en aard als Rawagedeh en Suid-Sulawesi' (<https://zoek.offi cielebekendmakingen.nl/stcrt-2013-25383.html >).

$26 \mathrm{Rb}$ Den Haag 27 January 2016, ECLI:NL:RBDHA:2016:702; Rb Den Haag 27 July 2016, ECLI:NL: RBDHA:2016:8642; Rb Den Haag 8 March 2017, ECLI:NL:RBDHA:2017:4448; Rb Den Haag 18 July 2018, ECLI:NL:RBDHA:2018:8525 (Kebon Agung).

27 HR 6 September 2013, ECLI:NL:HR:2013:BZ9225, BZ 9228.

28 Hof Den Haag 27 June 2017, ECLI:NL:GHDHA2017:1761 (Mothers of Srebreniça). 
issues of intergenerational justice (Subsection III.A). Continuing with the principle of restitution - justifying claims of unjust enrichment - we will see that it has been used to justify reparation of historical injustice, but that it is contested as well (Subsection III.B). The satisfaction of the victims is often used as a legitimation of reparation claims, but a closer look shows this to be a vague notion. Surely it is not feelings of revenge or resentment that tort law seeks to satisfy, so what do we mean exactly by (legitimate) satisfaction (Subsection III.C)? Finally, reparation of historical injustice may have distributive effects that ask for legitimation due to considerations of distributive justice (Subsection III.D). If the reparation of historical injustice results in a serious redistribution of scarce goods or life chances, the questions arises as to whether tort law and the civil court are the most appropriate institutions to provide for reparation (or whether public law and the legislator are more fit for the job). Here we lose track of the traditional legitimations in tort law. So ultimately, the question is what to opt for: compensation, restitution, satisfaction, or distribution?

\section{A Compensation}

The core of the principle of corrective justice is easy to grasp: 'if one agent has wrongfully harmed another, then the perpetrator has a prima facie moral obligation to repair, so far as possible, the damage to the victim. ${ }^{29}$ MacCarthy has sketched how a moral-political legitimation for reparations for slavery might be constructed on the premise of justice as fairness in a liberal democracy. At least until the 1960s, liberty and respect were denied under law to slaves and their descendants, with ill effects in the form of a gross social deprivation of Afro-Americans today. As a continuing constitutional undertaking, the United States is now under the moral-political obligation to redress the effects of those harms. This argument leads to the conclusion that corrective justice may serve as a justification of reparations for the historical injustice of slavery. At this stage this seems a non sequitur however, since it presupposes the intergenerational operation of the principle of corrective justice it seeks to justify. Additional arguments are needed, justifying why and how the principle of corrective justice bridges the gap between subsequent generations. These arguments are provided for, as we will see, but they are also disputed.

29 T MacCarthy, Coming to Terms with Our Past, Part II: On the Morality and Politics of Reparations for Slavery (2004) 32 Political Theory $750<$ http://www.jstor.org/stable/4148144>. 
Two attempts have been made to justify the intergenerational operation of the principle of corrective justice. The first is the so-called 'Broxill/Sher argument', which is based on the proliferation of wrongfulness over generations. Originally it sought to solve the non-identity problem: how can one claim compensation for historical injustice, without which one would not even have existed? Historical injustice not only determines people's fate, it also determines their very existence. ${ }^{30}$ How do we deal with that? One solution is the multiplication of liability. Wrongdoers not only owe compensation to their (direct) victims for the harms they have suffered, but also to their children for failing to compensate the parents if and when they had a duty to take care of their children. ${ }^{31}$ Of course, this argument can also be raised for these children's children, and so on. In fact, it justifies claims of an unlimited number of subsequent generations, on condition they are able to prove that they have suffered damage as a result of the non-compliance of the elderly duty of care. ${ }^{32}$ It is this condition that provides the missing link in descendant-based claims. The question was what is it that makes the wrongful act towards the direct victim wrongful towards his or her descendants (Subsection II.B)? The answer is the chains of duties of care that connect the subsequent generations.

The second, related attempt to bridge the intergenerational gulf is not so much based on the proliferation of wrongfulness as on the special nature of family ties. In his theory of justice, John Rawls already emphasised cross-generational duties of care in the so-called original state: 'What is essential is that each person in the original position should take care about the well-being of some of those in the next generation, it being presumed that their concern is for different individuals in each case. Moreover, for anyone in the next generation, there is someone who cares about him in the present generation. ${ }^{33}$ The special nature of intergenerational family ties - which is translated in most legal systems in a mutual duty of care - may constitute a good reason to shift the burden of proof from those who defend reparative claims to those that oppose them. ${ }^{34}$ This seems most evident in cases where descendants can claim an unconditional right to a family possession. What their forebears might have done with this possession - whether

30 J Thompson, Historical Injustice and Reparation: Justifying Claims of Descendants (2001) 112 Ethics 117: '(...) injustices not only affects how people fare. It can also determine what people there are.'

31 AI Cohen, Compensation for Historic Injustices: Completing the Broxill and Sher Argument, Philosophy and Public Affairs (Philos Public Aff) 37 (2008) 81.

32 Cohen, Philos Public Aff 37 (2008) 94: 'In this way, the Broxill/Sher argument can spun down generations.'

$33 \mathrm{~J} \mathrm{Rawls,} \mathrm{A} \mathrm{Theory} \mathrm{of} \mathrm{Justice} \mathrm{(1971)} 128 \mathrm{f}$.

34 Thompson, Ethics 112 (2001) 130. 
they would have gambled it, or invested it with good profits - is not that relevant. Entitlements that result from expressions of love and concern that are intrinsic to family relationships ought in any case to be regarded with the utmost respect: 'A society that wants to protect and promote these relations should give the claims of descendants the benefit of the doubt', so Thompson concludes..$^{35}$ In the case of slavery, an additional argument is that slavery itself is an injustice against the (establishment of) family ties. ${ }^{36}$

The question is, however, whether the sheer existence of family ties justifies such far-reaching consequences. Thompson herself refers to family ties as not merely a succession of generations but 'a narrative that connects past and present members and gives individuals a place and role in an intergenerational story of birth, death, marriage, family relationships, loss, and renewal. ${ }^{37}$ This raises the question: who is the narrator? Is it the one whose narrative is to justify a claim for compensation? How is the court to balance that with alternative narratives? Another question is how many generations down the line of family relations justify the benefit of the doubt for the claimants in reparatory cases? Rawls and others suggest (at least) two generations: the concerns of parents about the consequences of injustices inflicted upon them in general reaches beyond their children and their grandchildren. ${ }^{38}$ But what about the claims of Farmer Paellmann as the great-great-granddaughter of Clara and Abel Hinds? These questions suggest that the justificatory power of the principle of corrective justice may decrease over time. There is an argument for this suggestion. ${ }^{39}$ Historical injustice limits the life chances of the disadvantaged down the line, but the use they make of these chances is the result of their own doing. If this is true, subsequent generations have weaker claims for compensation, since more individual choices and actions interfere and their consequences cumulate. At the end of the day, there is little or nothing to compensate. Suppose a promising student is excluded from a prestigious law school. He gives up and misses a brilliant career. His children grow up in a middle class family and as a consequence miss the top-career they would have had if their father had not missed his. As a consequence, the disadvantage that subsequent generations suffer is the result of

35 Ibid.

36 Thompson, Ethics 112 (2001) 133.

37 Thompson, Ethics 112 (2001) 134. See also Hylton, BU L Rev 84 (2004) 1209.

38 Rawls (fn 33) 128: 'The parties are thought of as representing continuing lines of everlasting moral agent or institution. They need not take into account its entire life span in perpetuity, but their goodwill stretches over at least two generations.'

39 G Sher, Ancient wrongs and modern rights (1981) 10 Philos Public Aff 11; Cohen, Philos Public Aff 37 (2008) 101. 
their own choices and actions as well as those of their ancestors. The conclusion is that claims for compensation of historical injustice decrease with the passage of time.

An even more radical position is taken by Jeremy Waldron, who rejects intergenerational claims across the board if they have more than a symbolic meaning. First, Waldron has pointed out that historical injustice differs from actual wrongs (like the theft of my bicycle last week) in that their consequences may have disappeared as a result of social and economic developments. ${ }^{40} \mathrm{Next}$, Waldron reminds us that we simply cannot know in what position the plaintiffs would have found themselves if the wrongful act had not been committed. Possibly their ancestors would have gambled and lost their possessions. Because that would have been a consequence of their own free choice, this is not just an epistemological problem, but an ontological problem. ${ }^{41}$ Finally, Waldron warns that people build their lives upon their expectations about the legal entitlements of themselves and others. ${ }^{42}$ So if one wants to interfere with the legitimate expectations of people about the distribution of goods and chances, we better know what we are doing. Of course it is tempting to make the world look a little more like the world in which the injustice would not have taken place, Waldron reasons, but we should resist that temptation if it amounts to a complete redistribution of goods and rights: 'Reparation of historic injustice really is redistributive: it moves resources from one person to another. ${ }^{33}$ Whatever the merits of this conclusion, it reminds us that an all too generous interpretation of the principle of corrective justice amounts to an appeal to the principle of distributive justice.

\section{B Restitution}

An alternative to the torts model with regard to the liability for historical injustice is the unjust enrichment model. At first sight, claims on the ground of unjust enrichment offer considerable advantages for plaintiffs compared to claims on the ground of tort. Claims for restitutionary damages seem to have a lower threshold than claims for compensatory damages. Generally speaking, liability requires that one party is enriched at the expense of another party without due cause or reason-

$40 \mathrm{~J}$ Waldron, Superseding Historic Injustice, Ethics 103 (1992) 14, 24.

41 Waldron, Ethics 103 (1992) 9-11.

42 Waldron, Ethics 103 (1992) $18 \mathrm{f}$.

43 Waldron, Ethics 103 (1992) 13. 
able ground. ${ }^{44}$ Thus there is no need to establish wrongfulness on the side of the wrongdoer, or damage on the side of the victim. At closer look, however, the same problems arise in restitutionary cases as in compensatory cases. Was this defendant actually enriched at the expense of this plaintiff? What would have happened with the fruits of the labour of the ancestors of the plaintiff if these ancestors had been duly paid for their labour? Would these fruits have become part of the financial capital of the plaintiff? And did they - now that this has not been the case - actually become part of the capital of the defendant? And if such a transfer of capital has indeed taken place, was it without cause of reasonable ground, given that slavery was a legal institution at the time? Brophy is one of the authors who is willing to tackle these hurdles. First, he refers to cases on concrete objects, like houses. When a house was built with slave labour, restitution seems justified, even if the house has changed hands on the title of succession or sale. Next, he mentions the possibility of an intergenerational claim when the defendant has enjoyed benefits from which he still profits. He even considers it feasible that descendants of a slave actually claim the fruits of unpaid labour (an ancestorbased claim), or the damage of their own missed opportunities (a descendantbased claim). ${ }^{45}$

In the US, claims for restitutionary damages have become increasingly popular in cases of massive historical wrongdoing. From 1996 onwards, a series of class actions has been initiated by survivors of the Holocaust against Swiss banks for the theft and embezzlement of the assets of sleeping bank accounts, the money laundering of the revenues of goods that were stolen by the Nazis, and the trading with the profits of forced labour. ${ }^{46}$ The plaintiffs claimed, amongst others, restitution of unfair benefits. The cases were settled in 1998 for $€ 1,250,000,000$. In 1999, comparable claims were filed against other companies that had profited from forced labour during World War II, first in a case against the Ford Motor Company and its German counterpart ${ }^{47}$, and later in 56 other cases in different states. ${ }^{48}$ Finally in 1994, in a completely different context, a series of claims was filed by 46 states against the tobacco industry for the restitution of the benefits with which it was unjustly enriched. The alleged enrichment was the total sum of the health costs spent by the governments as a result of the use of tobacco, alleg-

44 P Gallo, Unjust Enrichment: A Comparative Analysis (1992) 40 The American Journal of Comparative Law (AJCL) 431, <https://www.jstor.org/stable/840566>; B Dickson, Unjust Enrichment Claims: A Comparative Overview (1995) 54 The Cambridge Law Journal (CLJ) 100.

45 Brophy (fn 6) 114.

46 In Re Holocaust Victim Assets Litig, 105 F Supp 2d 139, 141 (EDNY 2000).

47 Iwanowa v Ford Motor Co/Ford Werke AG, 67 F Supp 2d 424 (DNJ 1999).

48 These cases were settled by the German government for DM 10,000,000,000. 
edly on account of the industry. ${ }^{49}$ Characteristic for all these mass restitution claims is that they were filed against a private party (bank or corporation) for the financial equivalent of property or labour, enjoyed without reasonable ground at the expense of a group of disadvantaged. Thus the focus has shifted from the harm suffered by the disadvantaged to the profits enjoyed and/or the expenses saved by the defendants. Claims for restitutionary damages have in fact also been filed in slavery reparation suits as well (eg, in the case of Farmer Paellmann), but without success.

In spite of these substantive settlements on the basis of restitutionary damages, the appeal to restitution has been criticised. The core of the opposition is that the framing of a claim as unjust enrichment obscures the true nature of the historical injustice involved. This is not so much because these cases have been settled - with the result that the question as to the responsibility has not been answered satisfactorily - as rather because it remains unclear which specific norms were violated. Slavery can be framed as forced labour, of course, but that seems an impoverishment of the wrongful nature of slavery (as one of the severest violations of fundamental human rights). The focus on restitution of enjoyed benefits appears to result either in a reduction of slavery to an economic process (while it is essentially a legal and moral offence), or it leaves open which legal and moral norms were in fact violated (namely fundamental human rights). In either case, the restitutionary approach stops short as a legitimation of liability. As Sebok writes: 'The risk, therefore, in responding to slavery through the lens of unjust enrichment is that it fails to offer a legal characterization of the wrong that occurs when the non-commodifiable aspect of labor is violated.'50

This criticism has invoked a twofold reply of the proponents of restitution. The first line of defence is that the restitution of unjustly enjoyed benefits is in fact justified by a non-commodifiable aspect of labour, namely the infringement of the autonomy or the right to self-determination of the victim. Restitution is not just about money, so the argument goes. The restitution of the unjustly enjoyed benefits maintains and strengthens the autonomy of the victim. ${ }^{51}$ The second line of defence is that the restitution of unjustly enjoyed benefits is justified by its preventive effect. It is therefore an appropriate response to unwanted actions or practices like market-bypassing (the forced transfer of services or goods that

49 Again, these cases were settled for large sums of money: Mississippi in 1997 for \$3,300,000,000, Florida in 1997 for \$11,300,000,000, Texas in 1998 for \$15,300,000,000, Minnesota in 1998 for $\$ 6,100,000,000$ and the other states for $\$ 206,000,000,000$.

50 AJ Sebok, Two Concepts of Injustice in Restitution for Slavery (2004) 84 Boston University Law Review (BU L Rev), <http://ssrn.com/abstract=598258>.

51 Dagan, BU L Rev 84 (2004) 1139. 
could have been subject of a voluntary transaction) or unambiguously, socially undesirable conduct (conduct that brings high costs and barely or no benefits). ${ }^{52}$ In the case of slavery, both grounds offer a sufficient justification for restitution of the benefits. Of course, slavery is the most severe violation of the autonomy of those who are made slaves. Besides, slavery can be regarded as the ultimate market-bypassing (since labour can be subject of a voluntary transaction) as well as unambiguously, socially undesirable behaviour (according to current standards). What is more, these justifications also seem to hold in other cases of forced labour, like the case of the Sisters of the Good Shepherd. In those cases, restitution also appears to be a justified response to historical injustice.

The conclusion is that restitution is an alternative response to historical injustice. Compared to compensation, it seems to have advantages as well as disadvantages. For plaintiffs, a claim for restitutionary damages seems to have a lower threshold (wrongfulness and harm are not required) and possibly a better outcome (enjoyed profits may exceed suffered damage). ${ }^{53}$ Upon closer inspection, however, things turn out to be different. ${ }^{54}$ The assessment of the enrichment may be problematic and its unjustified character may be disputed (slavery was a legal institution at the time). As with the problem of legality, the argument can be raised that slavery was not so much legal but also excluded from the law (see Subsection II.A). Again, the justifying principle is that it is justified to place the burden of moral progress on the shoulders of those who profited from the lawless situation that is now being repaired, rather than on those who suffered from this situation..$^{55}$ If this makes sense, then the restitution of unjustly enjoyed benefits is a fitting and legitimate instrument to respond to historical injustice. From a macro perspective, however, restitution lacks the normative force of compensation, since the establishment of wrongfulness identifies the violated norms, whereas the normative force of restitution is limited to general principles (autonomy) and policies (preventive effects). Finally, the discourse on historical injustice in terms of enrichment may lead to uncomfortable debates on the 'historical guilt'. Is the guilt toward those who were subject to slavery (or their descendants) ever restorable? How is this calculable and how are performances or payments in return to be taken into account ${ }^{26}$ Our discomfort may partly be explained by the commodification of such an injustice, but also concerns the bigger question of whether

52 Hylton, BU L Rev 84 (2004) 1209.

53 Hylton, BU L Rev 84 (2004) 1209.

54 Brophy holds that harm is almost greater than benefit Brophy (fn 6) 104; Brophy, NYU Ann Surv Am L 58 (2003) 514.

55 Dagan, BU L Rev 84 (2004) 1139.

56 Brophy (fn 6) 109-114. 
satisfaction is within reach in the case of a historical injustice of this scale and meaning.

\section{Satisfaction}

Satisfaction is generally recognised as one of the 'softer' legitimations in tort law (next to storytelling, truth finding, strengthening accountability, norm development, contributing to the public debate, or even the collective awareness of society). In legal usage, it encompasses a broad range of cases, from the hurt feelings of the victim to the shocked legal order. In order to gain some conceptual clarity, I would like to propose two distinctions that together provide for a crossclassification. First, we have to distinguish between satisfaction at the individual level (as a remedy for the victim) and the societal level (as the restoration of the legal order). Next, we need to distinguish satisfaction in a psychological sense (the healing of emotions) from satisfaction in a moral sense (the reconfirmation of values). If we combine both distinctions, we can classify four kinds of satisfaction, all relevant in the case of the reparation of historical injustice.

The first kind of satisfaction is the healing of hurt feelings (in a psychological sense) at the individual level. The liability of the defendant often implies a recognition of the harm inflicted upon the victim or his or her descendants. This recognition may be more important to the victim than the compensation itself, it may even be his or her motive for action. In the case of the reparation of historical injustice, it may contribute to the healing of old wounds. The second kind of satisfaction is the social-psychological process of a society coming to terms with its past. This may be a traumatic event, such as the fall of Srebreniça in 1995. When this UN safe haven fell in the summer of 1995, this was disastrous for the victims, but it was traumatic for the Netherlands as well. The rulings of the Dutch Hoge Raad establishing the civil liability of the State of the Netherlands may have contributed to the process of coming to terms with this horrific event. Another example would be the reparation of slavery for a society that has still not come to terms with its consequences. ${ }^{57}$

The third kind of satisfaction is the reconfirmation of moral values at the individual level. For an individual plaintiff seeking redress, the recognition of the harm inflicted upon him or her, or his or her ancestors for that matter, may recon-

57 A personal note: during my visit to Suriname in November 2018, lecturing on this topic, I experienced an anxious audience, ready to discuss the reparation of the consequences of slavery, admitting that this still was an open wound in society. 
firm moral values that are constitutive for his or her self-image (as a moral person). Slavery is such a degrading institution because it destroys one's dignity as a person. Reparation therefore may contribute to the recovery of one's moral personality and the reconfirmation of one's moral values, such as equality and human dignity..$^{58}$ The fourth and last kind of satisfaction is the reconfirmation of moral values at the level of society at large. Reparation of historical injustice may help a society to come to terms with its past, as we saw, which may also reconfirm the values which constitute this society. A democratic society that has come to terms with slavery is based on values such as the recognition of human dignity, liberty for all men and women, equal concern and respect before the law. The reparation of the consequences of an institution such as slavery, which constituted a violation of these and other fundamental values, contributes to the collective memory of this derailment and thus to the reconfirmation of these constitutive values. The societal effect of such reparations may not be underestimated.

Satisfaction of the plaintiff is, however, not a legal consequence of liability, but at most a side effect. ${ }^{59}$ This implies that there may be means other than full compensation to cause the same psychological or moral effects. One may think of symbolic remedies (like a declaratory relief, an injunction for a symbolic step, or compensation for a symbolic sum), or even non-legal means (like public apologies, commemorations, exhibitions, statutes, revision of educational material, etc). Satisfaction may be better served by other means. On the other hand, not every legal remedy has the same moral or psychological force or power. Restitution seems to have less moral force than compensation, the reason being that unjust enrichment focuses on the benefits of the advantaged, not with the harm suffered by the disadvantaged. Restitution is directed at the confiscation of benefits, not at the reparation of harm. That is why restitution is morally less attractive than compensation. For this reason, one may have doubts as to whether restitution has the moral force to solve controversial societal issues about moral rights and duties, or the redistribution of goods and life chances. 'In other words', Sherwin writes, 'the notion of unjust enrichment is a comparative idea that draws on resentment and the desire for retaliation, rather than the desire to be made whole (...) For this reason, restitution seems out of place in a major public controversy, such as the debate on slavery reparations. ${ }^{60}$

58 For the effects of slavery on one's self-image see A Nicholson/M Dang/Z Trodd, A Full Freedom: Contemporary Survivors' Definitions of Slavery (2018) 18 Human Rights Law Review 689.

59 CE du Perron, Genoegdoening in het civiele aansprakelijkheidsrecht, preadvies NJV, in: AC Zijderveld/CPM Cleiren/CE du Perron (eds), Het opstandige slachtoffer, genoegdoening in strafrecht en burgerlijk recht (2003) 105.

60 Sherwin, BU L Rev 84 (2004) 1444. 


\section{Distribution}

Reparation of historical injustice may boil down to a redistribution of goods and life chances, as Jeremy Waldron has noted (see Subsection III.A). This may be a reason to reject the whole idea, as it was for him. Historical injustice may be overtaken by time, requires unjustifiable counterfactuals, may cause a floodgate of new claims, and eventually result in new injustices or even a total disruption of society. ${ }^{61}$ On the opposite side, there are those who find in the notion of distributive justice a legitimation for liability in cases of historical injustice. Since in most cases groups of victims are involved, the focus now shifts from the torts model and the unjust enrichment model - which are essentially individualistic, despite the possibility of class actions - to the moral-political notion of repairing damage. MacCarthy is one writer who supports such a shift in focus: 'From a moral-political perspective, it can be argued that, other things being equal, redressing the injuries to a group from past wrongs done to them has a certain priority over addressing the equity claims of other disadvantaged groups who are not victims of past injustice, because it has the weight of both distributive and corrective justice on its side. ${ }^{62}$

Is it necessary to take sides? On the one hand, I do not see a convincing argument to the effect that the circumstance that reparation requires redistribution is in itself prohibitive. It may be that there are overriding reasons of a moral or political nature to remember past injustices by repairing them. At the end of the day, this is a contextual judgment, where the responsibility of the court resembles that of a historian: 'The historian, like the judge, has the duty of constructing a jurisprudential narrative - an Aristotelian exercise that, insofar as it deals with individual or collective actions, proceeds with a case-by-case sifting. Being jurisprudential, it is also "prudential"; the narrative does not set Kantian categories as the criterion for plausible human behavior, but relies primarily on contextualization to establish what constituted culpable or nonculpable or even praiseworthy action. ${ }^{63}$ In the Srebreniça cases, the Dutch Hoge Raad clearly did find reason to construct such a jurisprudential narrative, as did the District Court of The Hague in the post-colonial cases.

On the other hand, to the extent that reparation involves a more radical redistribution, the counter-arguments gain weight. Besides, the court may ask itself whether it is the most proper institution for the job. In the case of Farmer Paell-

61 See J Spier, De lange schaduw van het verleden, omgaan met historisch onrecht (2016).

62 MacCarthy, Political Theory 32 (2004) 750.

63 Ibid. 
mann, the District Court of Illinois ruled that her claim constituted a non-justiciable political question, to be addressed by politics: 'In conclusion, based on the historical record presented here, it is clear that both during and after the Civil War the issue of reparations to former slaves was one committed to the Representative Branches of the federal government (...) By requiring the court to second-guess the decisions of the Representative Branches made more than a century ago, Plaintiff's Complaint presents a non-justiciable question. ${ }^{94}$ This conclusion basically summarises the judicial attitude in the US towards slavery reparations; not now, not this, but overall: not here. ${ }^{65}$

\section{Variables of claims for the reparation of historical injustice}

After researching the how- and the why-questions, we can address the whenquestion. Under what conditions are claims for the reparation of historical injustice most likely to be sustained? To be more specific, how can the differences in outcome between the slavery reparations suits in the US and the post-colonial cases in the Netherlands be explained? Why are the former rejected, while the latter are successful? Is this merely the result of differences in the tort law of both jurisdictions, or are there more structural differences and, if so, what are they?

\section{A The passage of time}

The first variable is, of course, the period of time that has lapsed, which we discussed in the context of (tolling or lifting) the statute of limitations and in the context of legality. With regard to the statute of limitations, we noted that the passage of time has normative significance: tort law claims fade away. ${ }^{66}$ of

64 In Re African-American Slave Descendants Litig, 375 F Supp 2d 721 (ND Ill 2005), referring to Cato $v$ United States, $70 \mathrm{~F} 3 \mathrm{~d}$ 1103, 1110 (9th Cir 1995) ('affirming the dismissal of plaintiffs' slavery reparations complaint on political grounds based on Congress' desire to prevent judicial secondguessing of legislative and administrative decisions grounded in social, economic, and political theory through the medium of action in tort').

65 Brophy (fn 6) 126: 'If there are going to be reparations, they will most likely not come from the courts, because of problems with locating a substantive basis for most suits and with locating appropriate plaintiffs and defendants, and because of the statute of limitations.'

66 Dagan, BU L Rev 84 (2004) 1139. 
course, this is the most obvious explanation for the different fate of the slavery reparation claims and the post-colonial claims: the former refers to a much older history than the latter, its narrative stretches over many more generations. But still, the claims of the widows of Rawagedeh would have been barred by the statute of limitations as well (like the slavery reparations claims) if it had not been lifted on grounds of equity and reasonableness. Tort law claims may fade away, but not necessarily at the same speed. The court's decision in this case makes the application of the statute of limitations dependent on the circumstances of the case, such as the nature of the injustice, the knowledge and actions of the parties, and the possibilities for the establishment of the facts. This undermines the clarity of the hard and fast rule, but opens the gate for reparation claims for historical injustice. Some reparation claims may be time-barred, others not, dependent on many circumstances of which the passage of time is only one.

Time is also relevant with regard to the wrongfulness of the acts involved. According to the decision of the court in the Rawagedeh case, the statute of limitations can only be tolled or lifted if and when the injustice was wrongful according to then prevailing standards. ${ }^{67}$ This requirement may be an obstacle for reparation claims, since both written and unwritten norms develop over time. Wrongfulness may therefore fade away (or come into existence), like tort law claims do. Some writers have argued, however, that slavery was not so much a legal practice as well as an 'a-legal practice' (beyond the legal domain, so to speak). ${ }^{68}$ This argument leads to a more nuanced approach to legality, since it allows that some practices may lead to a finding of liability now, although they were not wrongful according to prevailing standards then. I am referring to situations in which the victim was completely dependent on the wrongdoer, with no access to justice, and therefore de facto excluded from public life (with or without knowledge and consent of the government). Liability for historical injustice may therefore be justified - even if the conduct was not wrongful at the time - if and when the victims are intentionally excluded from the protection of the law.

A comparison with criminal law may be helpful. In deciding an English case of rape within marriage - which was not illegal under common law or written statutes in the United Kingdom at the time - the European Court of Human Rights judged that the conviction of the man did not constitute a violation of the principle of legality (as proscribed in art 7 of the ECHR). The reason is, according to the Court, that the conviction was foreseeable at the time and in accordance with the

67 Therefore slavery reparation claims would have had no chance in the Netherlands either.

68 As was the administration of justice beyond the reach of the slaves themselves. 
essence of the crime. ${ }^{69} \mathrm{~A}$ similar argument can be made in tort law. ${ }^{70}$ An act that was not wrongful at the time, but fills us with shame and disgust now, may lead to the establishment of liability if its wrongfulness was foreseeable for the wrongdoer and in accordance with the essence of the wrongful act. In those cases, the wrongdoer could and should have acted otherwise. An illustration would be the forced labour under harsh conditions of girls and young women at the Sisters of the Good Shepherd, where the nuns of the convent could have and should have acted otherwise.

\section{B The nature of the parties}

A second variable of the success of reparation claims is the nature of the parties and their connection with the historical victims and wrongdoers. We noted that victim-attenuation and wrongdoer-attenuation are obstacles for ancestor-based claims (Subsection II.A). For legal standing continuity through inheritance, family bonds or legal personhood is required, but for moral claims more proximity seems to be demanded. One of the reasons why the claims of the widows of Rawagedeh were stronger than those of Farmer Paellmann is that they were so close to the direct victims that they can be regarded as victims themselves (whereas Paellman was separated by five generations from the direct victims).

Besides, both the plaintiffs and the defendants may be individuals, groups of persons (in class actions), or legal persons (corporations or a State). Reparation claims seem to be morally stronger when they are made by or against individuals, that is, if they exemplify the torts model and (to a lesser extent) the unjust enrichment model, rather than to the moral-political notion of repairing damage (Subsection III.D). One explanation is that individual interests are more transparent and less controversial in this context than the public interest of a redistribution of goods and life chances on historical grounds. Reparation claims of a moralpolitical nature - especially when filed against the government - primarily serve public interests and thus exemplify public interest litigation.

69 European Court of Human Rights (ECtHR) CR v United Kingdom, 22.11.1995, no 20190/92.

70 Why should we apply stricter standards for legality in tort law than in criminal law? The other way around seems to make more sense. 


\section{The remedies claimed}

A third variable is the nature of the remedies claimed. The plaintiffs in the Rawagedeh case claimed declaratory relief, which was sustained. Farmer Paellmann, on the other hand, claimed a large sum of money - in the form of restitutionary damages, compensatory damages, and punitive damages - which was rejected. The first claim saved the court from addressing the unsolvable problem of the assessment of damages, which in itself would justify a rejection. As the court wrote: 'In essence, the Plaintiffs seek reparations from Defendants for their alleged roles in the institution of Human chattel slavery as it existed in the United States from 1619 through 1865, to date.'

In general, reparation claims seem more successful if and when they seek more symbolic remedies. The possibilities have not been exhausted yet. One may think of declaratory relief in the form of a moral-legal declaration with more substantive content than just the establishment of liability, or injunctive relief in the form of court orders to make symbolic gestures for reparation (like apologies, commemorations, exhibitions, educational material, etc). Reparative claims may also aim at finding the truth about specific historical incidents. ${ }^{71}$ These remedies enhance the chances of success since they do not require the establishment of specific wrongful acts and causal chains; a more general explanatory narrative suffices to connect past harm to present disadvantages.

\section{The moral legitimation}

Another difference between the Rawagedeh claims and the claims of Farmer Paellmann is that the first have a much stronger moral legitimation. They are justified by the principle of compensation, which - as we have seen (Subsection III. A) - is only disputed in intergenerational cases. The claim of Farmer Paellmann rests mainly on the principle of restitution, which - as we have seen (Subsection III.B) - has a weaker moral force. The satisfaction sought by the plaintiffs seems therefore more justified in the former case than in the latter (Subsection

71 See eg Rb Den Haag 25 July 2018, ECLI:NL:RBDHA:2018:8895 (train hijacking), in which the court made great efforts to find out what exactly happened. The question was whether hijackers were deliberately killed by the military that liberated the hostages. This fits with the 'largely untold story of the tort system's remarkable success in bringing the scandal to light, focusing on attention on the need for institutional reform, and spurring Church leaders and public officials into action' (TD Lytton, Clergy Sexual Abuse Litigation: The Policymaking Role of Tort Law (2007) 39 Connecticut Law Review (Conn L Rev) 809). 
III.C). Besides, the distributive consequences are insignificant in the first case, whereas they are huge in the second case (Subsection III.D). Farmer Paellmann found much more opposition on her path than the widows of Rawagedeh, and rightly so. All in all, compensation for the widows of Rawagedeh fits perfectly well in the legitimation patterns of tort law, whereas sustainment of the claim of Farmer Paellmann is much harder to fit in.

\section{E Political considerations}

At the end of the day, political considerations play a key role in the judgement of reparation claims. In the Introduction, we noted that the question as to whether to forget historical injustices or to remember by repairing them is not an innocent question, since it involves a 'democratisation' of the past and therefore a revival of political debate, this time about the meaning of history. Neither is the question of whether tort law is an instrument for reparations an innocent question since it stretches tort law to its limits, and sometimes beyond (Section I). Finally, there is the question of whether the civil court is the most appropriate institution for reparations, or whether the legislator is more suitable. It may be that the District Court of The Hague is more activist than the District Court of Illinois (Subsection III.D), or it may be the result of the cases that were brought before them.

\section{Conclusions}

Is tort law a remedy for historical injustice? The answer to our central question is that tort law can only be a remedy for historical injustice under specific circumstances.

First we addressed the question of how reparation is to be claimed and what kind of obstacles the plaintiffs find on their way (Section II). In this context, I highlighted the distinction between ancestor-based claims and descendant-based claims to be useful. Ancestor-based claims are based on wrongfulness, causality and harm in the past ('past harms'), for which compensation is sought now. The most important obstacles are the statute of limitations, victim- and wrongdoerattenuation, and the wrongfulness at the time. Descendant-based claims address the damage inflicted upon the plaintiff, who seeks redress for the 'present ill-effects' of injustice inflicted in history. The most important obstacles are (again) the statute of limitations, the relativity of the wrongful act towards the plaintiff, and the act-attenuation in the form of long causal chains. 
Next, I investigated what good reasons there are for reparation claims, and how they fit in the legitimation patterns of tort law (Section III). It turned out that the moral backbone of tort law - the principle of compensation - is contested in an intergenerational context. In attempts for reparation, justice-seekers often appeal to the principle of restitution instead, but it has weaker moral force than the principle of compensation and fails to identify the exact nature of the injustice to be repaired. The satisfaction of the plaintiffs seems to play a prominent role in reparation cases, both in a psychological and in a moral sense, and both on the individual level and the level of society at large. The interests of individuals seeking redress may coincide with the public interests of a society trying to come to terms with its past. The Srebreniça cases from the Netherlands form an illustration.

Finally, I draw conclusions in the form of some of the most important variables of the success of reparation claims, such as the passage of time, the nature of the parties, the remedies claimed, the moral legitimation, and the political considerations (Section IV). In comparing the claims of the widows of Rawagedeh and Farmer Paellmann, I hypothetically identified some of the differences that might explain the success of the former and the failure of the latter, independent of the substantive differences between the jurisdictions in which they were brought to court. Hopefully this contributes to our understanding of a new development of tort law that will not leave its limits and foundations untouched. 